\section{BMJ Paediatrics Open}

\title{
Codeine dispensing for privately insured children in the USA: a retrospective database study
}

\author{
Lucas Oliveira J e Silva (i) , ${ }^{1}$ Jana L Anderson, ${ }^{1}$ Fernanda Bellolio, ${ }^{1,2}$ \\ Ronna L Campbell, ${ }^{1}$ Molly M Jeffery ${ }^{1,2}$
}

To cite: Oliveira J e Silva L, Anderson JL, Bellolio F, et al. Codeine dispensing for privately insured children in the USA: a retrospective database study. BMJ Paediatrics Open 2021;5:e001321. doi:10.1136/ bmjpo-2021-001321

- Additional supplemental material is published online only. To view, please visit the journal online (http://dx.doi.org/ 10.1136/bmjpo-2021-001321).

Received 13 October 2021 Accepted 24 November 2021

\section{Check for updates}

\section{(C) Author(s) (or their} employer(s)) 2021. Re-use permitted under CC BY-NC. No commercial re-use. See rights and permissions. Published by BMJ.

${ }^{1}$ Department of Emergency Medicine, Mayo Clinic, Rochester, Minnesota, USA ${ }^{2}$ Division of Health Care Delivery Research, Mayo Clinic, Rochester, Minnesota, USA

\section{Correspondence to} Dr Molly M Jeffery; jeffery. molly@mayo.edu

\section{ABSTRACT}

In this retrospective study using claims data from the OptumLabs Data Warehouse including 24658769 eligible person-years of coverage in the USA, there was substantial decline in codeine dispensing between 2010 and 2019. However, we also observed a persistence of codeine prescribing despite the FDA contraindication in 2018. In 2019 , codeine was still being prescribed to children aged 12-17 years at 934 prescriptions per 100000 personyears of coverage and 106 per 100000 person-years of coverage in children aged $<12$ years.

\section{INTRODUCTION}

Codeine is a prodrug that is metabolised in the liver to morphine to produce analgesia and antitussive effects. The metabolism is based on the cytochrome P450-2D6 (CYP2D6) genotype, which is highly variable and can result in differing amounts of morphine produced. Even with standard dosing, ultrarapid metabolisers will produce significant morphine which may cause respiratory depression and possible death, particularly in children with a history of obstructive sleep apnea. ${ }^{1-3}$ Beginning in 2013, the US Food and Drug Administration (FDA) released increasingly restrictive warnings and ultimately recommended against the use of codeine-containing products in patients under age 18 (table 1$).{ }^{4}$ In this context, little is known about how paediatric codeine prescribing changed over time in the USA, including periods before and after the main FDA Drug Safety Communications (DSC).

\section{METHODS}

We performed a retrospective database study of privately insured children (age $<18$ years) who received one or more prescriptions for codeine, opioids other than codeine or nonopioid cough and cold medications between 1 January 2010 and 31 December 2019. We used pharmacy claims from the OptumLabs Data Warehouse (OLDW), a database containing over 150 million unique individuals across the USA who are privately insured and/or Medicare beneficiaries. The OLDW includes $20 \%$ of the commercially insured population in the USA, with similar distributions of age, sex and race or ethnicity to the US commercial population. This study was deemed exempt from review by the Institutional Review Board.

We used the National Drug Code Directory to categorise drugs containing codeine, opioids other than codeine and non-opioid cough and cold medications. A list of drugs evaluated in each group is available in online supplemental file 1 .

We analysed prescriptions dispensed in children aged $<12$ years and those aged $12-17$ years (same age groupings used in codeinerelated FDA DSCs). Descriptive statistics are reported as prescriptions dispensed per 100000 age-group person-years of coverage.

\section{Patient and public involvement}

There was no patient or public involvement in this study.

\section{RESULTS}

We identified 24658769 eligible person-years of coverage. Codeine dispensing declined over the entire study period in both children under 12 years and those aged 12-17 years. In children $<12$ years, codeine dispensing decreased $97.2 \%$ (from 3760 in 2010 to 106 per 100000 person-years of coverage in 2019). In older children aged $12-17$ years, codeine dispensing decreased $78.9 \%$ (from 4433 in 2010 to 934 in 2019). These declines were greater than the declines in opioids other than codeine (age $<12$ years, declined $58.3 \%$ from 2104 to 877 ; age $12-17$ years, declined $61.4 \%$ from 10439 to 4031 ). They were also greater than the changes in nonopioid cough and cold medications (age $<12$ years, declined $52.6 \%$ from 7980 to 3784 ; 
Table 1 Main Food and Drug Administration (FDA) drug safety communications restricting the use of codeine in children in the USA

\begin{tabular}{|c|c|c|}
\hline Date & Safety announcement & Main evidence behind announcement* \\
\hline 20 April 2017 & $\begin{array}{l}\text { Contraindication for the use of } \\
\text { codeine to treat pain or cough in } \\
\text { children aged }<12 \text { years. } \\
\text { Boxed warning recommending } \\
\text { against the use of codeine } \\
\text { in adolescents (age 12-17 } \\
\text { years) who are obese or have } \\
\text { conditions such as obstructive } \\
\text { sleep apnea or severe lung } \\
\text { disease. }\end{array}$ & $\begin{array}{l}64 \text { cases of respiratory depression, including } 24 \text { deaths, with codeine- } \\
\text { containing medicines in children aged }<18 \text { years. Fifty of the } 64 \text { cases } \\
(78.1 \%) \text { occurred in children aged }<12 \text { years. } \\
\text { Of the } 24 \text { cases reporting death, } 21 \text { ( } 87.5 \%) \text { occurred in children aged<12 } \\
\text { years. The reasons for codeine-containing medicine use in these cases } \\
\text { included post-tonsillectomy and/or adenoidectomy pain management, } \\
\text { other postoperative pain, general pain, sore or strep throat pain and cough } \\
\text { and cold. Although few cases mentioned the status of CYP2D genotype, } \\
\text { ultrametabolisation remains a key suspected driver of these adverse } \\
\text { events. }\end{array}$ \\
\hline $\begin{array}{l}11 \text { January } \\
2018\end{array}$ & $\begin{array}{l}\text { Safety labelling changes } \\
\text { contraindicating the use of } \\
\text { prescription opioid cough and } \\
\text { cold medicines containing } \\
\text { codeine in children aged }<18 \\
\text { years. }\end{array}$ & $\begin{array}{l}\text { After FDA review of the data and discussion with a panel of outside } \\
\text { experts, there was a conclusion that the risks of slowed or difficult } \\
\text { breathing, misuse, abuse, addiction, overdose and death with these } \\
\text { medicines outweigh their benefits in patients younger than } 18 \text { years. }\end{array}$ \\
\hline
\end{tabular}

${ }^{\star}$ These are based on information provided in the drug safety communications published in the FDA's website.

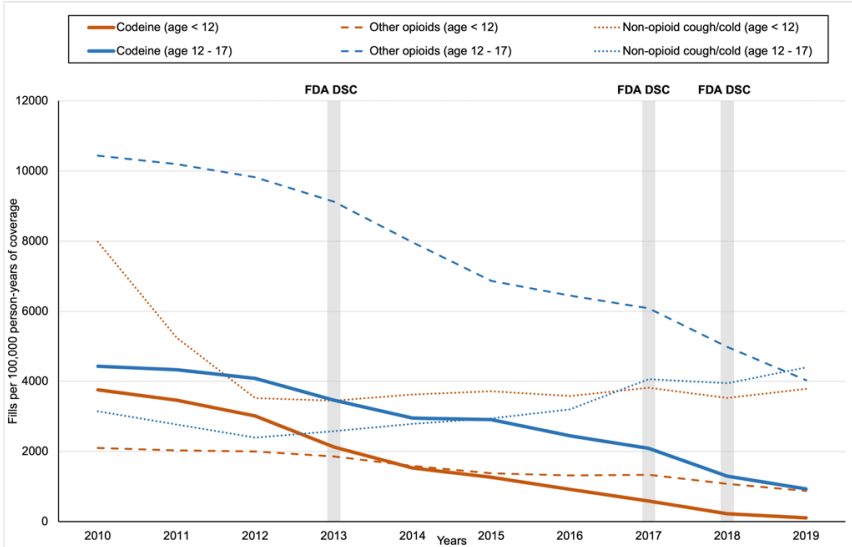

Figure 1 Trends of codeine-containing prescription fills in privately insured children compared with other opioids* and non-opioid cough and cold medicationst. *Most prescriptions dispensed for opioids other than codeine were medications containing hydrocodone and oxycodone in children aged $<12$ years. In children aged $12-17$ years, most prescriptions dispensed were medications containing hydrocodone, oxycodone or tramadol. †In both age groups, most prescriptions dispensed for non-opioid cough and cold medications contained dextromethorphan. The decline in prescriptions dispensed for non-opioid cough and cold medications for children under 12 years of age from 2010 to 2012 was mostly driven by a decrease in dextromethorphancontaining medications. DSC, Drug Safety Communication; FDA, Food and Drug Administration. age 12-17 years, increased $39.8 \%$ from 3149 to 4400 ). For both age groups, the largest single-year decline in codeine dispensing was from 2017 to 2018: for children $<12$ years, codeine dispensing declined $61.2 \%$ (from 586 to 228); for children aged 12-17 years, codeine dispensing declined $38.1 \%$ (from 2094 in 2017 to 1295 in 2018). Figure 1 illustrates these trends. Trends of codeine prescriptions separated by pain or cough indications are available in online supplemental file 2.

\section{DISCUSSION}

Codeine dispensing in children has declined substantially between 2010 and 2019, including the most severe restriction in early 2018 during which the FDA made codeine contraindicated. These relative declines were specific to codeine versus other opioids and versus nonopioid cough and cold medications and were greatest in the year the most severe restriction was issued. While FDA restrictions were temporally associated with a decrease in codeine use, prescribing was already declining prior to the first DSC for both codeine and non-codeine products. In 2019, codeine was still being prescribed to children aged 12-17 years at 934 prescriptions per 100000 person-years of coverage and 106 per 100000 personyears of coverage in children aged $<12$ years. Other studies have also showed the persistence of codeine prescribing despite an absolute FDA contraindication. ${ }^{56}$ Efforts to 
cease the use of codeine in paediatric patients need to continue.

\section{Twitter Lucas Oliveira J e Silva @lucasojesilva12}

Contributors Conceptualisation: JLA, FB and MMJ. Formal analysis, methodology, project administration, supervision, validation and guarantor: MMJ. Writingoriginal draft: LOJS and JLA. Investigation, writing — review and editing and provided critical revision and contribution for important intellectual content: All authors.

Funding This study was in part supported by the James $\mathrm{H}$. and Helen $\mathrm{F}$. Crossingham Emergency Medicine Career Development Award (number TN005446), an intramural research funding given to JLA.

Competing interests None declared.

Patient consent for publication Not applicable.

Ethics approval This study was deemed exempt from review by the Mayo Clinic Institutional Review Board.

Provenance and peer review Not commissioned; externally peer reviewed.

Supplemental material This content has been supplied by the author(s). It has not been vetted by BMJ Publishing Group Limited (BMJ) and may not have been peer-reviewed. Any opinions or recommendations discussed are solely those of the author(s) and are not endorsed by BMJ. BMJ disclaims all liability and responsibility arising from any reliance placed on the content. Where the content includes any translated material, BMJ does not warrant the accuracy and reliability of the translations (including but not limited to local regulations, clinical guidelines, terminology, drug names and drug dosages), and is not responsible for any error and/or omissions arising from translation and adaptation or otherwise.
Open access This is an open access article distributed in accordance with the Creative Commons Attribution Non Commercial (CC BY-NC 4.0) license, which permits others to distribute, remix, adapt, build upon this work non-commercially, and license their derivative works on different terms, provided the original work is properly cited, appropriate credit is given, any changes made indicated, and the use is non-commercial. See: http://creativecommons.org/licenses/by-nc/4.0/.

ORCID iD

Lucas Oliveira J e Silva http://orcid.org/0000-0001-5388-9163

\section{REFERENCES}

1 Ciszkowski C, Madadi P, Phillips MS, et al. Codeine, ultrarapidmetabolism genotype, and postoperative death. N Engl J Med 2009:361:827-8.

2 Kelly LE, Rieder M, van den Anker J, et al. More codeine fatalities after tonsillectomy in North American children. Pediatrics 2012:129:e1343-7.

3 Tobias JD, Green TP, Coté CJ, et al. Codeine: Time to Say "No". Pediatrics 2016;138:e20162396.

4 FDA. Drug safety communication: FDA requires labeling changes for prescription opioid cough and cold medicines to limit their use to adults 18 years and older, 2018. Available: https://www.fda.gov/ drugs/drug-safety-and-availability/fda-drug-safety-communicationfda-requires-labeling-changes-prescription-opioid-cough-and-cold [Accessed 04 Jun 2021].

5 Chua K-P, Shrime MG, Conti RM. Effect of FDA investigation on opioid prescribing to children after tonsillectomy/adenoidectomy. Pediatrics 2017;140:e20171765.

6 Kohler JE, Cartmill RS, Kalbfell E, et al. Continued prescribing of periprocedural codeine and tramadol to children after a black box warning. J Surg Res 2020;256:131-5. 